\title{
Interoperability Challenges for ICT-enabled Governance: Towards a pan-European Conceptual Framework
}

\section{Gianluca Misuraca ${ }^{1}$, Giuseppe Alfano $^{2}$ and Gianluigi Viscusi ${ }^{3}$}

${ }^{1}$ European Commission, Joint Research Centre, Institute for Prospective Technological Studies, Seville, Spain, gianluca.misuraca@ec.europa.eu

${ }^{2}$ Centre for Social Informatics, Edinburgh Napier University, Scotland, United Kingdom, g.alfano@napier.ac.uk

${ }^{3}$ Università degli Studi di Milano Bicocca, Department of Informatics, Systems and Communication (DISCo), viscusi@disco.unimib.it

Received 12 August 2010; received in revised form 18 November 2010; accepted 22 December 2010

\section{Abstract}

In the European academic and institutional debate, interoperability is predominantly seen as a means to enable public administrations to collaborate within Members State and across borders. The article presents a conceptual framework for ICT-enabled governance and analyses the role of interoperability in this regard. The article makes a specific reference to the exploratory research project carried out by the Information Society Unit of the Institute for Prospective Technological Studies (IPTS) of the European Commission's Joint Research Centre on emerging ICT-enabled governance models in EU cities (EXPGOV). The aim of this project is to study the interplay between ICTs and governance processes at city level and formulate an interdisciplinary framework to assess the various dynamics emerging from the application of ICT-enabled service innovations in European cities. In this regard, the conceptual framework proposed in this article results from an action research perspective and investigation of e-governance experiences carried out in Europe. It aims to elicit the main value drivers that should orient how interoperable systems are implemented, considering the reciprocal influences that occur between these systems and different governance models in their specific context.

Keywords: Interoperability, Public administration, Cities, E-governance, European Union 


\section{Introduction: Linking Interoperability and Governance}

In the context of European policy and strategy for e-Government, Information and Communication Technologies (ICTs) are seen not only as a means of improving public services, but also a way of enabling multi-level governance. This multi-level or - as it is often referred to in EU official documents - "pan-European" governance, consists of an growing network of local and national administrations across the EU and of the emergence of a new and more integrated "European public space". The improvement of public service delivery on the one hand and the support for information sharing between ICT-enabled administrations on the other become fundamental aspects of institutional and policy legitimacy of the administrations themselves. In this "pan-European" context, ICTs assume a strategic and political significance in addition to a technical one.

For this reason, the concept of interoperability is developed mostly at a Community and supranational level in the European e-Government debate. Here interoperability is predominantly seen as a means of developing the crossborder dimension of e-Government amongst the public administrations of the different Member States. Over recent years, the issue of interoperability has become increasingly significant in the EU policy agenda. In the eEurope Action Plan [15], interoperability is explicitly mentioned as an essential prerequisite for European e-Government Services. At the Ministerial Conference held in Como in July 2003, Member States affirmed its increasing significance, stating that the development of "pan-European" services depends in part on the interoperability of information and communication systems used at all levels of government.

The explicitly declared aim of the European Interoperability Framework (EIF) [16], for example, is "to support the European Union's strategy of providing user-centred eServices by facilitating the interoperability of services and systems between public administrations, as well as between administrations and the public (citizens and enterprises), at a pan-European level". In the same way, European R\&D programmes on e-Government have implemented a significant number of projects to develop interoperability, with a particular reference to the supranational community level.

More recently, following the Malmö Ministerial Declaration (November 2009) and the Granada Ministerial Declaration on the European Digital Agenda (19 April 2010), the Digital Agenda for Europe [15] again puts emphasis on the key role of interoperability at a pan-European level.

Indeed, despite the efforts made by European institutions to develop interoperability frameworks, most effort has so far been directed towards the cross-border issues this raises and, as a result, its local dimension has remained under developed in the academic and institutional debate. In our opinion, the local dimension of interoperability has a critical and specific aspect that should be fully recognized by focusing on the distinctive characteristics this layer of Government represents. This is because:

- $\quad$ at the local level, interoperability plays a strategic role, especially in the governance of both on-line and offline services delivered to local communities.

- $\quad$ in Europe, most public services - not only e-Government services - are provided at a city or regional level by Municipalities or Regional Institutions.

- the European Commission affirms that efforts must be made to achieve interoperability at all layers of Government. The European Commission's Communication "Interoperability for Pan-European eGovernment Services" [17] states that "e-Government services are delivered at all levels of government. Interoperability must be ensured between local, regional, national and European administrations to provide seamless services".

However, while this makes the case for local interoperability, as suggested in the above mentioned European Commission Communication, it also serves to reframe the problem. For example, the European Commission Communication states: "the approaches and solutions for interoperability will differ, depending on the e-Government services concerned and on the environment in which the services are implemented" [17]. The local environment is characterized by a complex interplay between different specific elements: the organizational dimension of the institutions, the composite of the network relationships between public, private and civil society organizations, and, finally, the difference and the overlaps between the policy and functional areas involved. It is also important to note that, at the local level, EU Member States have richly diverse structural and cultural elements which shape their administrative systems and this diversity must be carefully considered. Indeed, the design of an interoperability framework must deal not only with technical or organizational elements - such as the integration of different business processes or information systems - but also with institutional and socio-economic issues. For this reason, the different European cultural administrative traditions - that influence, for example, the level of horizontal coordination between government agencies - must be taken into consideration in the analysis and elaboration of an interoperability framework focused on the local governance level. 
In this regard, the aim of this article is to define a framework focused on the local dimension of interoperable systems. The main topic of the article is the analysis of interoperability from a policy perspective, paying particular attention to the governance dimension, i.e. the complex network of relationships between all the actors and the public administration's stakeholders involved in the implementation and utilization of interoperable systems at the local level. For this reason, the article deals with structural elements, concepts and values that should orient how interoperable systems are implemented so that they can respond to requests not only in technical terms but, most of all, in the institutional and organizational field, as it is declared in the official statements quoted above.

Therefore, Section 1 is focused on the definition of interoperability and on the different levels of analysis it can be investigated from. In Section 2, we discuss the background of the research and its motivations. In Section 3, we discuss the methodological approach followed. Section 4 provides a conceptual framework in order to spell out all the different organizational, institutional and socio-economical dimensions that can be relevant in the implementation process of interoperable systems. Finally, in Section 5, we apply the model in the context of e-Governance and we identify the three main value drivers that should orient the implementation activity of interoperable systems.

\section{Background and Motivations}

In this Section we first present the scope and challenges linked to interoperability, outlining the multiple dimensions and characteristics of it. Then we discuss the motivation for proposing a conceptual model of interoperability contemplating a twofold level of analysis and based upon the theoretical framework and discussion developed within the exploratory research on emerging ICT-enabled governance models in EU cities (EXPGOV) [18] (Section 2.1). We further discuss (Section 2.2) the role of interoperability in ICT-enabled governance, arguing that a conceptual framework for interoperability should also be focused on the overall public value created by interoperable systems in supporting ICT-enabled governance. In this regard we define e-Government as a process of innovation of public administration, government and governance through the use of ICTs and we debate, building on current literature, key issues to be considered when evaluating public value, including the role of various stakeholders and the elements required to assess the improvement of a local governance system, the evaluation of different eGovernment policies in general and different interoperability strategies in particular. We then present the conceptual framework developed as part of the EXPGOV project and, with the purpose of providing the reference model to this article, we discuss the three main value drivers that constitute the basis of a theoretical framework for ICT-enabled governance, considered as an abstract construct which encompasses altogether the public value drivers identified.

\subsection{Interoperability Scope and Challenges}

In terms of technical definitions, an interoperability platform is a solution that enables two or more software applications to exchange data and achieve a common objective, even if these applications were not originally designed to cooperate. However, interoperability can take place at different governance levels, from the exchange of simple data items, to structured documents (e.g., a purchase order), to business process cooperation allowing different organizations to achieve a common objective with software applications that are interoperable [23]. To draw a comprehensive picture of the interoperability domain, three main dimensions must be taken into consideration: the layered strands, the interoperability scope, and the maturity level [90].

According to the European Interoperability Framework (EIF) and the UNDP e-Government Interoperability Study Group [50] there are three strands to interoperability: technological, semantic, organizational:

- Technological interoperability: This includes both hardware and software issues. The former mainly concerns connectivity and protocols (e.g., TCP/IP), while the latter concerns a common syntax (e.g. XML) for data, and also standards for messaging (e.g. SOAP and WSDL). A technological interoperability platform allows two organizations to reliably exchange messages, but the actual understanding of message content remains outside its scope.

- Semantic interoperability: This implies that, despite divergences in the structure, organization and content of the exchanged data, the intended meaning is correctly conveyed, the information is correctly acquired and the expected actions are understood and undertaken.

- Organizational interoperability: For an effective and far-reaching cooperation between two (or more) organizations, organizational interoperability also needs to be addressed. The latter means that the two (or more) cooperating organizations are able to effectively perform a cooperative task, exchanging information and services. Furthermore, this strand also includes the progressive adoption of best practices, necessary to ease an effective interoperability. Organizational interoperability is generally supported by adopting an appropriate framework, such as ebXML, TOGAF, or e-GIF.

The three above strands are interdependent. For instance, the user interface and the interaction methods (for civil servants and end users) require solutions that cut across the three strands. They also have an inherent progression, in terms of the achievable interoperability scope. 
The interoperability scope is the second dimension of the interoperability domain. The interoperability scope is determined by the kinds of objects that are considered and managed by the desired interoperability platform, namely: Simple data items; structured documents; services; processes; organization models; and strategies. However, it is not always necessary to achieve the ultimate scope. Interoperability initiatives should be undertaken considering the actual administrative needs and binding resources according to the defined objectives.

Finally, the maturity level concerns the organizational capacity to achieve interoperability. Interoperability is not a value per se; its value depends on the context of cooperation among organizational units and the benefits produced. When complex organizations start a process aimed at integrating their different databases and application systems, they should clearly define the progressive levels of interoperability they want to achieve. To help in this direction, administrations should adopt a layered maturity model for interoperability (Interoperability Maturity Model, or IMM). In order to achieve advanced and effective interoperability solutions, to consistently model the organizations involved in the interoperability process is a crucial precondition. The IMM (already adopted by many governments around the world, such as the Australian Government) closely follows the Capability Maturity Model Initiative (CMMI) framework, which consists of the following five maturity levels: initial; managed; defined; measured; and optimised.

Reaching each level requires the attainment of the previous level. The above levels can be applied to the desired interoperability objective, represented by the six items identified in the interoperability scope. Often, a fourth dimension is considered in the context of e-Government, related to territorial specialization (e.g. city, province, region, or nation, including both horizontal and vertical interoperability).

The thesis proposed in this article is that a conceptual model of interoperability focused on the local context should contemplate two distinct levels of analysis. The first level considers the perspective of the specific target category of ICT-enabled services, in order to calculate the benefits (or opportunity costs) for the local economy and community and the integration of the different business process and information systems. This analytical dimension can be called "service level of analysis" and it is mostly focused on technical issues and on the economic correlation between the outputs and the outcomes. A second complementary level of analysis underpinning the conceptual model should be focused on the interplay between the policy and institutional dimensions and the technical one. This second level of analysis looks at the benefits as well, but from a policy and organizational perspective - including public, private and third sector organisations in their role as service designers, providers or suppliers, or other. We refer to this dimension as the "governance level of analysis". For the institutions and the organizations involved in the restructuring and the integration of the information systems, interoperability is not only a technical challenge but also involves a significant change in policy strategies, in stakeholder relationships and in organizational structures.

The framework presented in this article is focused in particular on this second level of analysis. Its aim is to assess, with specific regard to the local level of policy implementation, which elements of a governance model can influence the integration of information systems and business processes of different institutions. Moreover the framework attempts to set the basis for assessing how ICT-enabled collaboration across organizational boundaries can be appropriately implemented in different European governance contexts. Finally, the article discusses what role interoperability can play in the overall context of a local (ICT-enabled) governance models.

In order to do this, the article makes explicit reference to the theoretical framework and discussion developed within the exploratory research on emerging ICT-enabled governance models in EU cities (EXPGOV) [18]. The EXPGOV project is being conducted by the Information Society Unit at the Institute for Prospective Technological Studies (IPTS), part of the European Commission's Joint Research Centre. The aim of the project is to study the interplay between ICTs and governance processes at city level in the EU context, by providing evidence of the changes that ICTs are producing on city governance models.

The research focuses on the way the different stakeholders interact when introducing ICTs into governance systems and the way these interactions affect institutions and communities, and the related decision-making process. Two main issues are specifically investigated: 1) the changes produced by ICTs on governance processes, (e.g. regulatory and legal frameworks, organisational and administrative procedures, roles of various stakeholders involved, etc.) and consequently the effects on decision-making, public management and service delivery; and 2) the socio-economic implications at policy level.

Within this context, evidence from research and fieldwork suggests that there is a need to overcome cultural and institutional barriers, and to mediate between the vertical bureaucratic governance models existing in many countries and the horizontal and cross-organisational collaborations associated with introducing ICTs. However, these changes often provoke fear and resistance [4], [38], [51].

In addition, introducing ICTs into governance systems unveils issues of strategic importance in different spheres of public governance - from legal to organisational to technological - which are linked not only to the service-delivery function of the State, but also the overall policy and regulatory cycle of the governance process. It is for this reason that a holistic approach should be adopted when implementing interoperability solutions. They, in turn, should be defined in terms of specific service needs, as well as the organizational requirements outlined by stakeholders themselves. 
To achieve this multi-level and inter-administrative approach, it is required to capture the co-evolution of ICT developments with the strategies set out by political institutions, at different levels of governance. Here interoperability can act as a dynamic driver, enabling cross-administration collaboration and opening governance processes to all stakeholders. Involving key actors in strategic development and fostering self-management is needed to succeed in ICT-enabled transformations.

In this perspective, the development of an assessment framework becomes critical. It must be capable of measuring the maturity level of an e-Government organisation, and evaluating the interoperability of an e-Government system. A comprehensive assessment of e-Government interoperability systems will help ensure the coherence between the initial investments and the final achievements.

\subsection{The Role of Interoperability in ICT-enabled Governance}

One of the main goals of the design and the implementation of interoperable systems should not merely be the enabling of multi-agency collaboration. As with many aspects of e-Government - and because interoperability is such an important element of it - a conceptual framework should also be focused on the overall public value created by interoperable systems in supporting ICT-enabled governance at the local level.

For instance, the OECD [44] broadly defines e-Government as a process of innovation of public administration, government and governance through the use of ICTs. This broad perspective requires that public managers evaluate an e-Government system according to its capacity to improve the overall performance of the organisation adopting it. This should also be true for interoperability systems, as these have become the essential backbone for eGovernment and e-Governance development processes.

From the Anglo-Saxon perspective, at least, public value refers to the value created by government through services, law regulations and other actions. The close relationship between the concept of public value and e-Government was first pointed out by Kearns [29]. In a critical discussion about the excessive emphasis given to online services as the central element of e-Government systems, Kearns states that public administration should aim to produce value for citizens. From this perspective, the use of ICTs to improve government and governance is a means of improving the production of public value. Thus, an e-Government system resulting from a process of technological and organisational innovation can be indirectly evaluated by considering the possible increase of public value deriving from the adoption of that system.

In general, public value-based evaluation must be performed by considering the value that citizens perceive in their interactions with public administration [1]. Discussing the value of ICTs for public administration, Bannister underlines that the definition of value reflects the fact that citizens interact with public administration playing different roles [2]. We can extend this idea to the relationship between public administration and the wide spectrum of its stakeholders, such as private organizations, NGOs and suppliers. As a starting point, we take the following classification of roles, proposed by Bannister, as referenced and further elaborated in Castelnovo and Simonetta [5]:

- $\quad$ external roles, in which citizens receive value from public administration as users of services or participants in democratic processes;

- internal roles, in which citizens, directly or indirectly involved in the processes of production of value, nevertheless receive public value from a public administration (because, for instance, it works well);

- $\quad$ mixed roles, which are external to public administration and yet involved on different levels in the production of public value, as is the case of ICT-enabled Governance systems.

The last category is closely related to the implementation of interoperability systems, which could be considered one of the most important structural elements of an ICT-enabled governance system linking public administration and its stakeholders to their constituencies.

Since the interactions between stakeholders and public administration can concern both stakeholders as users (mostly citizens) and stakeholders as operators of public administration (mostly private organizations and suppliers), public value can be measured both from an external point of view (stakeholders as users) and from an internal point of view (stakeholders as operators). In the first case, the policies for e-Government can be evaluated with respect to the quality of the services delivered; in the latter case they can be evaluated with respect to their ability to improve the system of local governance.

Therefore, in order to assess the improvement of a local governance system, the evaluation of different eGovernment policies in general and different interoperability strategies in particular should consider whether these increase: 
- $\quad$ the degree of policy integration in homogeneous territorial areas;

- the organizational and operational simplification of the individual institutions forming the governance network;

- $\quad$ their capability to maintain cooperative relations with other administrations, suppliers and associations.

All these results can only be achieved if the aggregations (for example at city or community level) that are set up remain stable over time and if the various relations and effects (not only from a technical perspective) are considered in a 'dynamic' manner.

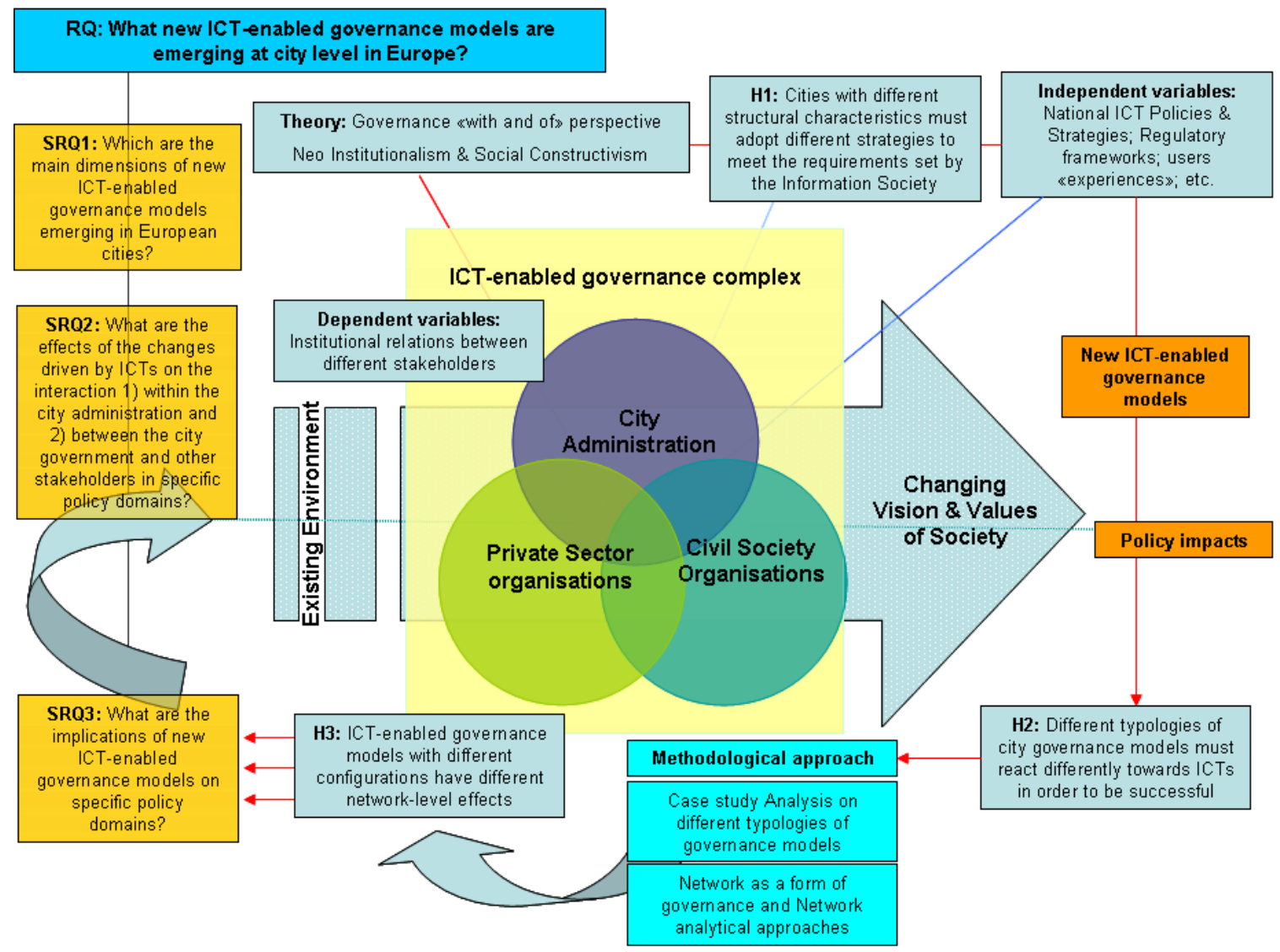

Figure 1: Synopsis of the conceptual framework proposed by the EXPGOV project

Figure 1, directly drawn from the conceptual framework of the EXPGOV project, attempts to outline in a synoptic manner the complexity of an ICT-enabled governance system at local level. It shows clearly how the different elements of an ICT-enabled governance system are tied together in a complex dynamic of interconnected effects. In particular, figure 1 shows the inputs and outcomes of a city governance model, in which the dependent variables are the institutional relations between the city administration, the private sector and the civil society organizations that are enabled by ICTs and network technologies. The ICT-enabled institutional relations can be influenced by a number of independent variables, such as national ICT policies and strategies, regulatory frameworks, the existing network relations in the institutional environments and, finally, the users' experience and the organizational approach to the use of ICTs. A city governance model must identify the interconnection between these elements and their possible policy impacts.

This article will focus on this complex interconnection. However, before doing so, it is worth paying some attention to the definitions of the concepts of governance, e-Governance and what we define as ICT-enabled governance because of their significant relevance in the design process of interoperable systems at the local level.

The term "governance" is used in several contemporary social sciences, especially economics and political science. It originates from the need in economics (as regards corporate governance) and in political science (as regards state governance) for an all-embracing concept capable of conveying diverse meanings not covered by the traditional term "government". Government, in fact, is only one of the actors in governance. The concept of governance has been studied from different perspectives and in different disciplines with evolving definitions and variations of interpretations. In political science and sociology, the concept of governance can be also described as a "process of 
transforming and reformulating approaches to public affairs which involves developing systems for ordering the various players at local level in societies" [27]. This approach is in line with another definition developed by the UN, which sees governance as "a multifaceted compound situation of institutions, systems, structures, processes, procedures, practices, relationships, and leadership behaviour in the exercise of social, political, economic, and managerial/administrative authority in the running of public or private affairs" [49].Therefore governance cannot be considered to be a matter of government only. It is a situation of multiple inter-linkages and relationships in which different actors in the public and private sectors as well as civil society play different roles - sometimes mutually conflicting and sometimes mutually reinforcing and complementary - focusing on satisfying the interests of the local community. In this sense, local governance involves the management of administration at local level, including interadministrative and inter-sectoral linkages with various partners and stakeholders.

Therefore, in our research, we define governance as the process of decision-making and the process by which decisions are implemented, monitored and evaluated. In fact, the multiple dimensions of governance - the structures, roles and relationships governing how society functions - are constantly evolving. These changes are strongly conditioned by historical transformations in society's underlying values and organisational models and can be analysed from several research perspectives [42]

Indeed, ICTs are important tools to support transforming governance processes. In recent years, we have witnessed a proliferation of tools and ICT-based initiatives, mainly addressing public service delivery and administrative processes that can be placed under the banner of the e-Government phenomenon, and also develop innovative forms of local service delivery [37], [41].

Although the concept of e-Governance is not commonly recognized and shared worldwide as a complementary activity inherently different from e-Government, we define e-Governance as the field of activity where policy design, decision-making, co-ordination, arbitration, networking and regulation, with ICTs, but also of ICTs, take place [34]. This involves the relationships of all governance actors - the state representatives being, however, the main stakeholders - and the evolving dynamics resulting from these interactions, in terms of organisational forms, processes, outcomes and impacts from the perspective of both the government and the citizens [22], [35]. eGovernance can therefore be considered as a broad framework to capture the co-evolution of ICTS' various stakeholders with the political institutions, at local, national and global level. In this perspective, e-Governance can also be regarded as a multidimensional construct encompassing ICT research, at the intersections with social, economic, political, and organizational science research, and addressing the investigation of the missions of government in relation to the interests of society [39], [42].

In this connection, the EXPGOV project at IPTS proposes a new concept, that of ICT-enabled governance, as the use of ICTs to comprehensively simplify and improve the internal administrative operations of government. ICTenabled governance, in fact, facilitates public service interaction between government, citizens and other stakeholders. Moreover, it enables citizen participation and ensures inclusiveness and equal opportunities for all [42]. This concept is put forward as a comprehensive framework enfolding a broad range of informal and formal descriptions including, for example, policy and decision making, strategic and operational processes, legal and organisational structures and inter-actor relationships. The framework is therefore put forward as a meta-construct, including the concepts of e-Government and e-Governance as well as complementary concepts and practices defined as e-Inclusion, e-Participation, e-Democracy and other inter-relationships.

In this connection, the specific analysis of ICT impacts at organizational and policy levels are informed by neo institutionalism perspectives [13], [20]-[21], combined with constructivist approaches to policy and socio-political institutions, such as the ones developed by Hay [25] or Schmidt [46]. Thus this analysis of ICT-enabled governance is placed within the broader framework of network theory. In fact, networks have been widely recognized by both scholars and practitioners as important forms of multi-level governance. The advantages of network coordination (especially if they are ICT-enabled) in both private and public sectors are considerable, and include enhanced learning, more efficient use of resources, increased capacity to plan and address complex problems, greater competitiveness and better services for clients and customers [36]. Research in the field of ICT-enabled governance at the local level should therefore be related, on the one hand, to the influence ICT-solutions have on the quality of the relationship between government, its constituency and stakeholders and, on the other hand, to the assessment of the degree in which ICT-enabled networks support new patterns of 'connection'.

In this regard, the EXPGOV Project aims to formulate an interdisciplinary framework to assess the various dynamics emerging from the application of ICT-enabled services and innovations in city governance contexts (see Fig. 1). The Project focuses on social, organizational and technological issues as key elements for the definition of the institutional and policy changes involved in the implementation of ICTs in European city governance contexts. In this perspective, the role the EXPGOV Project attributes to interoperability is just between the social, organizational and technological aspects of an ICT-enabled governance model as defined above. As will be shown in the following, interoperability is considered a key element of an ICT-enabled governance model.

Making reference to recent work in the area of social studies, public policies and ICT [51], the EXPGOV theoretical framework argues in favour of the adoption of a wide definition of e-Government as a system of ICT-enabled innovation policies for public administration and related governmental functions. In this view, ICT-enabled projects - 
and the implementation of interoperability systems are included as part of this category - can be considered highlevel, context-sensitive interventions which aim to introduce and facilitating gradual changes [11]. In this connection, the EXPGOV project has identified three main value drivers that constitute the basis of a theoretical framework for ICT-enabled governance at the local level. We consider an ICT-enabled governance model as an abstract construct which encompasses the following public value drivers:

Value driver 1- Performance: this includes effectiveness and efficiency (enabling optimal use of resources for citizens and tax payers in service delivery); and, indirectly, responsiveness (serving all citizens in a consistent and predictable way).

Value driver 2 - Openness: this includes access to information as a proxy for participation (enabling the process of empowering citizens to legally control service delivery to their advantage) and transparency (bringing visibility to the service workflow for citizens by means of automated service delivery); and accountability (creating standards against which the individuals providing a service and the service delivery can be held accountable), that also serves the goal of ensuring consensus orientation (following democratic practices).

Value driver 3 - Inclusion: this includes equity and inclusiveness (referring to citizens receiving the service on an equal basis and providing services to disadvantaged and minority groups in society), which implicitly ensures respect for the rule of law (ensuring that laws and regulations governing the service are applied in an impartial way).

These three dimensions are an attempt to describe, from a policy and organizational perspective, the aims that all governance (and thus interoperability systems) should have, independently from their technical and operational characteristics. The objective of the specification of these dimensions is to satisfy and harmonize different demands implied in the implementation of interoperable systems. In our considered opinion, representatives, public managers and practitioners involved in the implementation of interoperable systems should be oriented by abstract systems and general aims in their activity, regardless of the administrative tradition, the institutional context and organizational culture in which their work is conducted.

In this perspective, they are a relevant construct for the conceptual framework proposed in Section 4 but first we will discuss the methodological approach followed for the design of the conceptual framework.

\section{Methodological Approach}

The methodological framework of this article addresses the theoretical approaches of research in social studies on ICT-enabled innovations and policies, grounded on the assumption that there is a reciprocal influence between social and technological issues. This assumption is recognized as a core element of the approaches sharing a sociotechnical perspective [8],[48], that conceive social and technical sub-systems as interdependent, and deal with the reciprocal fit between social and technical solutions within the innovation process.

The conceptual model - which is the main outcome of this article - points out the design nature of the methodological approach. Indeed, as discussed in [32], a design science framework is composed of two axes, namely research activities (building, evaluating, theorizing on and justifying artefacts) and research outputs (constructs, models, methods and instantiations), see also [26].

Furthermore, as regards research activity, the article is based on the authors' experiences in assessing European and international projects on e-government, governance and interoperable systems, e.g. in [35], [42], [51]. A first draft of the conceptual framework and the related constructs has been produced on the basis of the cited experiences, and qualitative evaluations have been carried out on primary and secondary data from those experiences and from deliverables available from other projects. Due to the interaction between theory and practical experience in projects, the research approach that we follow is close to Action Research. Action Research is an iterative research process involving researchers and practitioners acting together in a particular cycle of activities, including problem diagnoses, action intervention, and reflective learning [3], [7]. In the following Section, we discuss the proposed conceptual framework and its main constructs.

\section{Conceptual Framework}

ICT applications to support transforming governance processes and innovative forms of local service delivery have been developed in pioneering experiments and pilot projects in several large and medium-sized cities all over the EU. For example, a flagship programme to structure and systematize interventions, as well as to support best practice sharing and cross-administration collaborations, is the UK Local e-Democracy National Project which ran from 2004 to 2006 and sought to explore how new technologies could change the way in which municipal councils engage and work with their citizens and communities [28]. This project set out to explore in more detail issues concerning eDemocracy (e-Participation in local democratic engagement) within the broader local e-Government strategy and programme in the UK. More recently, during 2006 and 2007, the EUROCITIES [19] network carried out a survey about e-Government City Models entitled "e-Government City Models: cases from European cities" [45]. This survey, which constitutes a qualitative approach to e-Government in European cities, shows how seven leading European 
cities have faced up to the transformation of their governance processes over the past ten years. It investigates the key decisions taken and the main inspirations for their policies. The research therefore provides a valuable tool for city managers to initiate and guide the e-Government transformation.

Based on the analysis of state-of-the-art research and practice in this field, it can be observed that experiments and pilot projects are taking place at different governance levels. However, it appears that it is at the city level that the appropriate use and integration of ICTs in the governance mechanisms can best support social and institutional innovation. They can empower officials and community representatives; ensure social inclusion; provide efficient, services; improve the management of administrative operations; facilitate planning and policy making processes; monitor and record political decisions and assess related socio-economic impacts in the municipalities and their locale. However, while it is recognized that interoperability plays a key role for ICT-enabled governance, research in this domain, especially at local and city level, is lacking, especially with regard to the non technical dimensions of the phenomenon, and with specific regard to the relation between interoperability and governance processes. Due to these issues, we propose here a conceptual model built on the basis of the authors' previous experiences and on analysis of the state of the art in research and literature on ICT-enabled governance (see previous sections).

The conceptual model represented in (figure 2) aims to elicit different configurations of Interoperable governance systems on the basis of the relationships between the following factors:

- Governance models characteristics (i.e. the cultural administrative tradition and socio-economic characteristics of the context of intervention),

- $\quad$ Value drivers (i.e. performance, openness, inclusion).

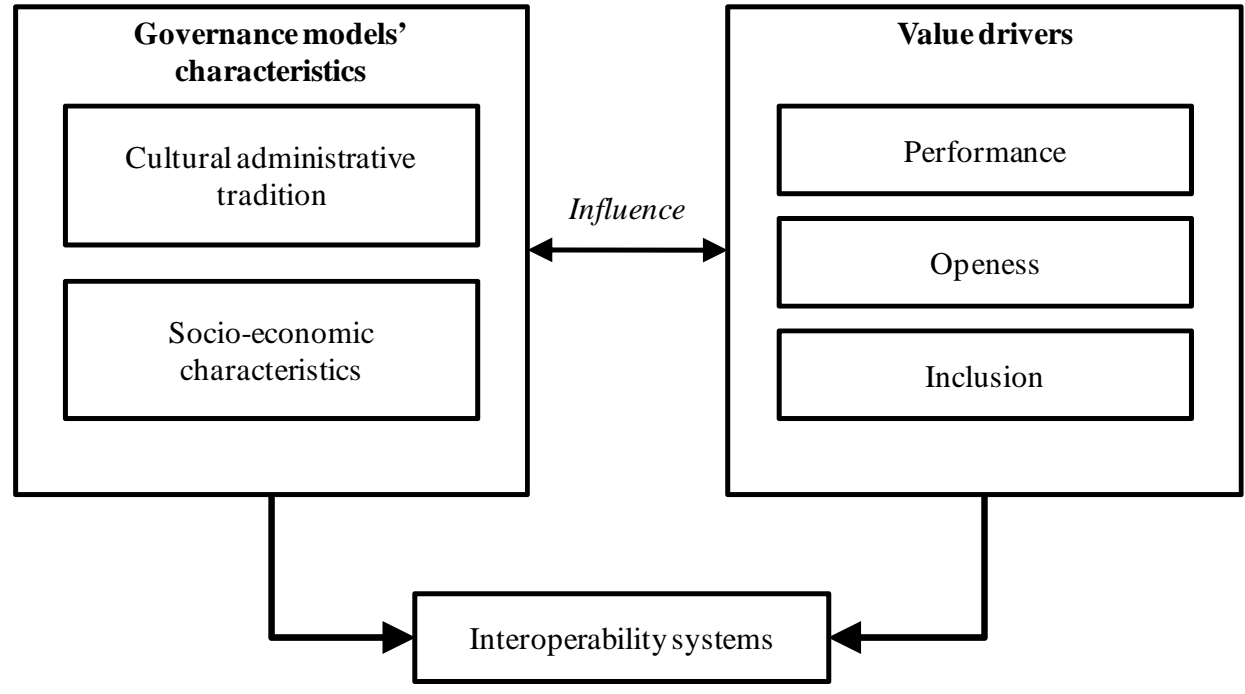

Figure 2: The conceptual model

Furthermore, the conceptual model in (figure 2) aims to provide an interpretative instrument to deal with the multiple facets and layers of ICT-enabled interoperability and governance. Up until now, scholars and public managers have had few instruments that allow a systemic perspective of the challenges of these multiple facets, and a silo representation of interoperability has prevailed.

In the following Section, we apply the conceptual framework to discuss the main characteristics of governance models in different EU countries and describe the value drivers of Interoperable systems in ICT-enabled governance.

\section{The Influence of the Characteristics of Governance Models on Interoperability Systems}

In this Section we discuss the conceptual model shown in (figure 2). First, we consider dimensions for the analysis of governance models characteristics, i.e. cultural administrative traditions (Section 5.1) and socio-economic characteristics (Section 5.2). The aim here is to provide a preliminary application of the model at European level, in terms of classification of cultural administrative tradition and typology of governance systems. Subsequently, we point out the challenges of considering socio-economic factors in terms of city and urban characteristics.

Finally in Section 5.3 we discuss the impact and role of interoperability on the value driver influenced by the above discussed governance models characteristics and related dimensions. Furthermore we provide for each driver a set of quality dimensions suitable to enable a better interpretation of the type of contribution offered by interoperability initiatives. 


\subsection{Cultural Administrative Traditions}

A challenging aspect of the elaboration of a conceptual framework for ICT-enabled governance at the local level consists of the need to consider the diversity and complexity of different urban contexts when discussing the interoperability of governance systems in Europe. As emphasised by eminent scholars of public administration such as Bouckaert, Loeffler, and Pollitt in their speeches delivered as scientific rapporteurs at the closing plenary of Rotterdam 3QC conference, the context and differences in terms of cultural and administrative traditions matter and naïve imitation of experiences without considering the peculiarity of national contexts are bound to fail.

This applies particularly to interoperability. In fact, despite the European Interoperability Framework and several National Interoperability Frameworks which have already been developed and proposed as best practices, a single European model of e-Government interoperability has yet to emerge. Many countries are still struggling to implement interoperable solutions in both the private and public sector, at local, national or at pan-European level. This is because EU Member States present a very rich diversity of structural and cultural elements that shape their administrative systems. A synthetic and selective list of key dimensions of comparison and differences is presented in (figure 3) below which is adapted from the work of Esping-Andersen [14].

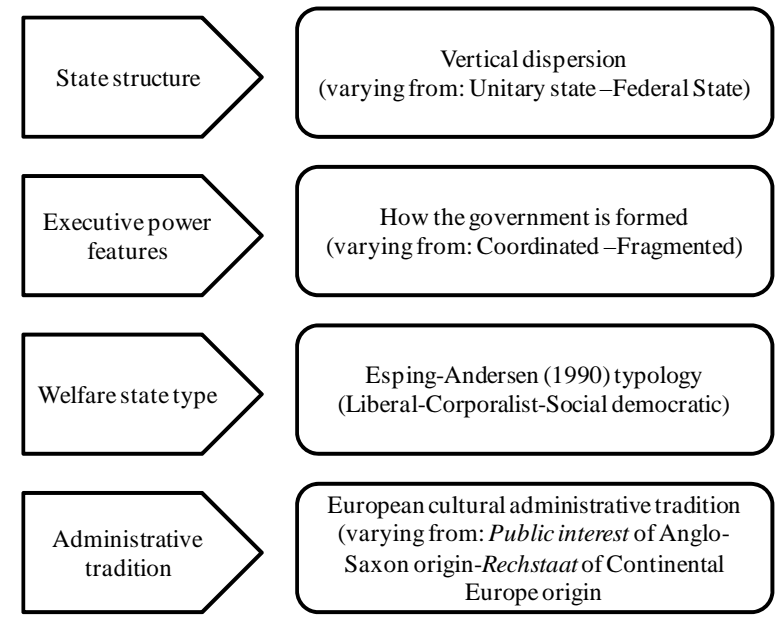

Figure 3: Key dimensions of public administration system comparison

Among the main dimensions in figure 3 , the administrative traditions have a relevant impact on effective ICT-enabled interoperability and governance (for the sake of brevity and space we won't discuss the other dimensions proposed and we refer the reader to [14]).

Table 1: Key features of administrative traditions

\begin{tabular}{|c|c|c|c|c|}
\hline & Anglo-Saxon & Germanic & French & Scandinavian \\
\hline $\begin{array}{l}\text { Is there a legal basis } \\
\text { for the "State"? }\end{array}$ & No & Yes & Yes & Yes \\
\hline $\begin{array}{l}\text { State-society } \\
\text { relations }\end{array}$ & Pluralistic & Organicist & Antagonistic & Organicist \\
\hline $\begin{array}{l}\text { Form of political } \\
\text { organization }\end{array}$ & Limited federalist & Integral/organic federalist & $\begin{array}{l}\text { Jacobin, "one and } \\
\text { indivisible" }\end{array}$ & $\begin{array}{l}\text { Decentralized } \\
\text { unitary }\end{array}$ \\
\hline Basis of policy style & Incrementalist & "Muddling through" legal & Corporatist legal & $\begin{array}{l}\text { Technocratic } \\
\text { consensual } \\
\end{array}$ \\
\hline $\begin{array}{l}\text { Form of } \\
\text { decentralization }\end{array}$ & $\begin{array}{l}\text { "State power" (US); } \\
\text { local government (UK) }\end{array}$ & Cooperative federalism & $\begin{array}{l}\text { Regionalized unitary } \\
\text { state }\end{array}$ & $\begin{array}{ll}\text { Strong } & \text { local } \\
\text { autonomy } & \\
\end{array}$ \\
\hline $\begin{array}{l}\text { Dominant approach } \\
\text { to discipline of } \\
\text { public } \\
\text { administration }\end{array}$ & $\begin{array}{l}\text { Political } \\
\text { science/sociology }\end{array}$ & Public law & Public law & $\begin{array}{l}\text { Public law } \\
\text { (Sweden); } \\
\text { Organization theory } \\
\text { (Norway) }\end{array}$ \\
\hline Countries & $\begin{array}{l}\text { UK; US; Canada (but } \\
\text { not Quebec); Ireland }\end{array}$ & $\begin{array}{l}\text { Germany; } \quad \text { Austria; } \\
\text { Netherlands; } \quad \text { Spain } \\
\text { (after } \\
\text { 1978); Belgium (after 1988) }\end{array}$ & $\begin{array}{lr}\text { France; } & \text { Italy; } \\
\text { Netherlands; } & \text { Spain } \\
\text { (until } & \text { 1978); } \\
\text { Portugal; } & \text { Quebec; } \\
\text { Greece; } & \text { Belgium } \\
\text { (until 1988) } & \\
\end{array}$ & $\begin{array}{ll}\text { Sweden; } & \text { Norway; } \\
\text { Denmark } & \end{array}$ \\
\hline
\end{tabular}


With regard to state traditions we identified Anglo-Saxon, Germanic-organicist, French-Napoleonic, and Scandinavian, following [31] as further elaborated by Codagnone [10]; on this basis we summarize the key features of European administrative traditions in Table 1. In summary, in Europe we can find, first of all, unitary states, federal states and various versions of unitary decentralised or regionalised states. The level of horizontal coordination within government can range from high to very low in cases of fragmented executives characterised by a great deal of competition and negotiation among ministries and agencies. European welfare states vary quite considerably in the extent to which their labour markets are regulated and benefits are guaranteed. Finally, cultural administrative tradition, with an analytical simplification, can be positioned at different points of the continuum between the two ideal types: public interest and Rechtsstaat traditions [9].

All other things being equal, unitary states with high levels of horizontal coordination and a system of majority rule should be in a better position to introduce uniform innovation reforms than decentralised states with low levels of horizontal coordination and consensually-formed governments, where a lot of negotiation and compromise are needed. However, there is a risk of an extreme top-down approach which could create a lack of ownership at the lower levels where innovation reforms must be implemented.

On the other hand, in consensualist systems, if agreement is reached on what to do, there are fewer lower-level ownership problems. In federal states, there is also the opportunity for particular regions to become places for experimentation and innovation. The actual reality of European public administration is certainly more complex and blurred than the two ideal types outlined above, nonetheless these differences exist and do matter. Looking specifically at the use of ICTs in government, the picture becomes even more complex. An illustration of the different development of e-Government in relation to different cultural administrative traditions in Europe has been developed by Millard and Iversen [33], see Table 2.

Table 2: Cultural administrative traditions and e-government development in EU-27

\begin{tabular}{|c|c|c|c|c|c|}
\hline $\begin{array}{l}\text { Denmark, Sweden, } \\
\text { Finland, } \\
\text { Netherlands } \\
\text { (Nordic \& Dutch) }\end{array}$ & $\begin{array}{l}\text { UK, Ireland } \\
\text { (Anglophone) }\end{array}$ & $\begin{array}{l}\text { France, Belgium, } \\
\text { Luxembourg } \\
\text { (Francophone) }\end{array}$ & $\begin{array}{l}\text { Germany, Austria } \\
\text { (Germanophone) }\end{array}$ & $\begin{array}{l}\text { Italy, Spain, } \\
\text { Portugal; } \\
\text { Greece } \\
\text { (Latin) }\end{array}$ & $\begin{array}{lr}13 & \text { Eastern } \\
\text { Europe } \quad \text { and } \\
\text { Mediterranean } \\
\text { states }\end{array}$ \\
\hline $\begin{array}{l}\text {-History of freedom } \\
\text { of information. } \\
\text {-Stress on e- } \\
\text { Government as part } \\
\text { of 'informed } \\
\text { democracy'. } \\
\text {-Notion of active } \\
\text { government not } \\
\text { necessarily viewed } \\
\text { with suspicion. } \\
\text {-Strong role for local } \\
\text { democracy }\end{array}$ & $\begin{array}{l}\text {-e-Government } \\
\text { seen as a } \\
\text { response to } \\
\text { 'new economy' } \\
\text { and hence } \\
\text { driven by by } \\
\text { business needs. } \\
\text {-Emphasis on } \\
\text { transactional } \\
\text { services to } \\
\text { increase efficiency. } \\
\text {-But also strong } \\
\text { role for non- } \\
\text { governmental } \\
\text { civic institutions. } \\
\text {-For citizens } \\
\text { concerns about } \\
\text { privacy may } \\
\text { retard development. } \\
\text { denent }\end{array}$ & $\begin{array}{l}\text {-Tradition of strong } \\
\text { civic pride, strong } \\
\text { public sector, and } \\
\text { centralised state. } \\
\text {-Mainly centralised } \\
\text { state structures, } \\
\text { making relatively } \\
\text { easy to integrate } \\
\text { e-Government } \\
\text { services, though } \\
\text { many recent } \\
\text { changes. }\end{array}$ & $\begin{array}{l}\text {-Tradition of strong } \\
\text { civic pride, strong } \\
\text { public sector. } \\
\text {-Federal structure } \\
\text { with relatively weak } \\
\text { centre making it } \\
\text { relatively difficult to } \\
\text { integrate } \\
\text { Government } \\
\text { services. }\end{array}$ & $\begin{array}{l}\text {-Strong role for } \\
\text { non- } \\
\text { governmental } \\
\text { civic institutions. } \\
\text {-Importance of } \\
\text { city regions } \\
\text { leading e- } \\
\text { Government } \\
\text { development, } \\
\text { such as e.g. } \\
\text { Barcelona or } \\
\text { Bologna. } \\
\text {-Central } \\
\text { government role } \\
\text { in } \\
\text { standardisation } \\
\text { and funding, but } \\
\text { not necessarily } \\
\text { in development. }\end{array}$ & $\begin{array}{l}\text {-Former } \\
\text { command } \\
\text { economy states } \\
\text { have a strong } \\
\text { tradition } \\
\text { centralised of } \\
\text { bureaucracy and } \\
\text { universal public } \\
\text { services, even if } \\
\text { at low level. } \\
\text {-As transition } \\
\text { societies, } \\
\text { opportunities exist } \\
\text { to leapfrog both } \\
\text { technically and } \\
\text { organisationally to } \\
\text { front-runner } \\
\text { positions if } \\
\text { investments can } \\
\text { be found. } \\
\text {-Mediterranean } \\
\text { states of Malta } \\
\text { and Cyprus share } \\
\text { many of the } \\
\text { characteristics of } \\
\text { Southern Europe, } \\
\text { although have a } \\
\text { recent colonial } \\
\text { British past, which } \\
\text { still affects } \\
\text { government and } \\
\text { structures and } \\
\text { mindsets. }\end{array}$ \\
\hline
\end{tabular}

In addition to this, when talking about city governance, other issues should be taken into consideration, such as the competences delegated to municipal and local governments, and the role of city government within the overall framework of the structure of the state. Without going into detail, as this would be clearly outside the scope of this article, we propose in Table 3 below a simple overview of the governance models (at country level) according to the key dimensions identified above (figure 3), but limited to the dimension of state structure. Table 3 is taken from the Concept Paper of the EXPGOV Project and was elaborated by IPTS for this project [18], [42]. 
Table 3: Typology of state governance systems in the EU-27

\begin{tabular}{|c|c|c|c|c|}
\hline Typology & Unitary state & Decentralised unitary state & $\begin{array}{l}\text { Regionalised unitary } \\
\text { state }\end{array}$ & Federal state \\
\hline Description & $\begin{array}{l}\text { Existence of local level } \\
\text { infra-national hierarchy } \\
\text { only. Regional levels may } \\
\text { exist for administrative } \\
\text { reasons but are } \\
\text { subordinate to the central } \\
\text { state }\end{array}$ & $\begin{array}{l}\text { States which have } \\
\text { undertaken a process of } \\
\text { reform to establish elected } \\
\text { regional authorities above the } \\
\text { local level }\end{array}$ & $\begin{array}{l}\text { Characterised by the } \\
\text { existence of elected } \\
\text { regional governments with } \\
\text { constitutional status, } \\
\text { legislative powers and a } \\
\text { high degree of autonomy }\end{array}$ & $\begin{array}{l}\text { Power-sharing } \\
\text { guaranteed by } \\
\text { the constitution }\end{array}$ \\
\hline $\begin{array}{l}\text { EU-27 } \\
\text { countries } \\
\text { typology }\end{array}$ & 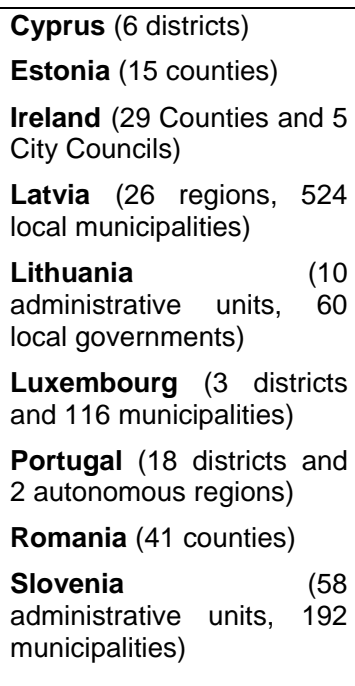 & $\begin{array}{l}\text { Denmark (5 regions and } 98 \\
\text { municipalities) } \\
\text { France (22 regions) } \\
\text { Finland (5 provinces and } 1 \\
\text { autonomous region. } 415 \\
\text { municipalities) } \\
\text { Hungary (19 departments } \\
\text { and } 19 \text { counties) } \\
\text { Malta (3 regions, } 68 \\
\text { municipalities) } \\
\text { Netherlands (12 provinces } \\
\text { and } 467 \text { municipalities) } \\
\text { Slovakia (79 districts and } 8 \\
\text { regions) } \\
\text { Sweden (20 counties and } \\
290 \text { municipalities) } \\
\text { United Kingdom (4 regions } \\
\text { and devolution process }\end{array}$ & 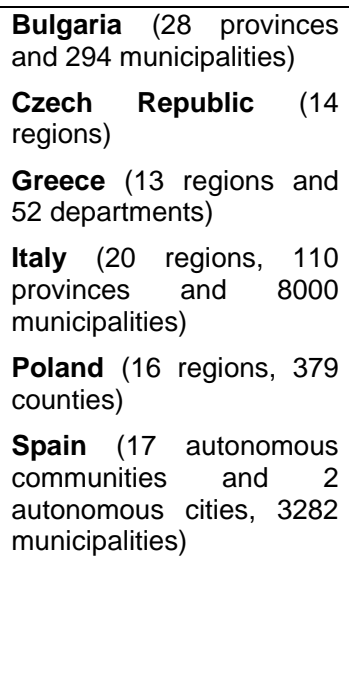 & $\begin{array}{l}\text { Austria } \\
\text { landër) } \\
\text { Belgium } \\
\text { regions and } \\
\text { communities) } \\
\text { Germany } \\
\text { landër) }\end{array}$ \\
\hline
\end{tabular}

The broad differences between the administrative and cultural traditions of European governance models are also transferred to the city level and have implications for the way we can define and analyse ICT-enabled governance models. These administrative and cultural traditions in fact present both areas of convergence and divergence with respect to the governance model of reference. The implication of these considerations for the design of an interoperability framework at the local level in Europe is that, when defining an ICT-enabled governance model at the level of the city government, we should also consider the administrative traditions and cultural context in which ICTs are applied. More specifically, if one wants to assess interoperability and the degree of shared/joined-up services, one must remember that the likelihood of achieving this objective also depends on the governance structure of the state (not only at the city level) and it is reasonable to assume it is more difficult to achieve in decentralised and federalist states. Further research is needed, however, on how the structural and cultural elements that shape the different administrative systems traditions in Europe can affect a given ICT-enabled governance model. The literature in the field is very poor, and this fact evidently testifies to the importance and the urgency of an in-depth analysis of the possible correlation between key features of administrative systems and interoperability frameworks implemented at the local level. Though we do not aim to offer a solution here, we believe nevertheless that it is important to indicate possible new topics for future research in e-Government and e-Governance and to spell out the main elements of administrative systems that researchers should assess in their investigations.

\subsection{Socio-economic Characteristics}

Cultural administrative traditions are not the only element that can influence the success of the implementation of an interoperability system at the local level. It could be hypothesized that cities with different structural characteristics and socio-economic conditions must react differently towards ICTs in order to be successful. Different types of cities, then, must adopt different strategies that are suitable for the characteristics of each specific socio-economic context.

In order to reduce the complexity as well as to facilitate the comparison and the benchmarking amongst different cities it would help to classify cities and urban regions in Europe referring to its possible impact on ICTs and urban development. For this purpose, there are various models for classifying city regions developed since the 1990s [6], [24], [30]. Most of them distinguish at least between prospering city regions and old industrial regions. Very useful as a basis for classifying cities according to their economic-functional rank is the model offered by [30]. This model, approaching the structural change of city systems as a process of economic-functional hierarchisation, takes into account that studies focussing on population trends and degrees of urbanisation are not useful. In Europe cities ranked first in terms of population are often not the strongest economic centres (e.g. Berlin, Rome). Also the degree of urbanisation of a country is not a good indicator. There are countries with high degrees of urbanisation but great difference in economic strength (Spain, Germany), vice versa there are countries with similar economic power but 
different degrees of urbanisation (UK, Sweden). Therefore Krätke classifies the European city systems along the following components: a) quality and range of controlling capacities, finance and service functions and b) degree of specialisation on innovative or traditional production structures (ibidem).

It is evidently behind the scope of our work to discuss in details the characteristics of an economic-functional model to classify cities and urban regions in Europe. But we should take into consideration the fact that these economicfunctional features reflect those characteristics of cities relevant for the interrelations of ICTs in governance systems and urban development in general. Economic and social characteristics could be correlated to current prospective trends affecting city governance systems and interoperability systems in particular, especially by taking into account the trends of globalisation and 'cultural localisation' further reinforced by ICTs as a spatial and functional amplifier of decentralisation and sub-urbanisation. Due to the pervasiveness of ICTs which might reinforce polarisation within the European urban systems, in fact, large cities with high population trends could be seen as forerunners of ICTenabled innovations and pioneers in adopting new ICT-enabled governance models.

Although this is slightly in contrast with the aforementioned Krätke's model, this hypothesis is borne out by several studies in the field of organizational change. They postulated that large cities tend to be more inclined to innovation [43], [47], [12]. A reason for that could be that larger cities face a more complex environment. Therefore on one hand municipalities or public agencies of large cites are more pressed by the demand of innovative services, on the other hand they have more organizational freedom to experiment new solutions. For example, with specific regard to eGovernment, in his study West [52] found that the only statistically relevant factor to be positively correlated with the degree of e-Government rankings amongst U.S. cities was the total population.

\subsection{Interoperable Governance Systems: The Value Drivers}

In this sub-section, we discuss the impact and role of interoperability on the value drivers influenced by the above discussed governance models characteristics and related dimensions (figure 2). Furthermore, we provide for each driver a set of governance dimensions and quality dimensions, which are suitable to enable a better interpretation of the type of contribution offered by ICT-enabled initiatives (see Table 4). The relevance of a systemic perspective on quality assessment supporting strategic planning of e-Government initiatives is inspired on the framework proposed and discussed in [51] and applied for e-Governance initiatives [38].

Table 4: Value driver, governance dimensions and related quality dimensions

\begin{tabular}{|c|c|c|}
\hline Value Driver & Governance Dimension & Quality dimension \\
\hline \multirow{4}{*}{ Performance } & \multirow[t]{3}{*}{ Efficiency } & Economic \\
\hline & & Temporal \\
\hline & & $\begin{array}{l}\text { Procedural (i.e. the obligations and constraints imposed by law on the } \\
\text { administrative processes and on the interactions between } \\
\text { administrations and users) }\end{array}$ \\
\hline & Effectiveness & $\begin{array}{l}\text { Service Reliability, including Accuracy and Completeness of information } \\
\text { requested for the service provision in order to achieve the user's } \\
\text { expectation }\end{array}$ \\
\hline \multirow{6}{*}{ Openness } & \multirow[t]{2}{*}{ Access to information } & Temporal \\
\hline & & Cultural \\
\hline & \multirow[b]{2}{*}{ Interoperability } & $\begin{array}{l}\text { Technological (i.e. diffusion of standards and technological } \\
\text { infrastructures and systems for interoperability) }\end{array}$ \\
\hline & & $\begin{array}{l}\text { Shared data / services (i.e. the ability of administrations to access data } \\
\text { by means of the inter-administration back office, and the possibility for } \\
\text { external users to access administrative data via ICTs) }\end{array}$ \\
\hline & \multirow[t]{2}{*}{ Accountability } & $\begin{array}{l}\text { Transparency (i.e. the volume of information that the public } \\
\text { administration provide to users describing their internal functioning and } \\
\text { informing users on what they can expect or claim while using the service) }\end{array}$ \\
\hline & & $\begin{array}{l}\text { Participation (i.e. the effective level to which users' opinions reach the } \\
\text { public administration in charge of the service and influence the provision) }\end{array}$ \\
\hline \multirow{4}{*}{ Inclusion } & \multirow[t]{2}{*}{ Accessibility } & Service accessibility for disabled people \\
\hline & & $\begin{array}{l}\text { Technological (i.e. diffusion of the infrastructure and technologies which } \\
\text { support the service provision) and channel accessibility (i.e. it focuses on } \\
\text { the existence of different channels for service access and delivery, such } \\
\text { as desktop PC, mobile phone, TV and radio, etc.). }\end{array}$ \\
\hline & \multirow[t]{2}{*}{ Equity } & ease of access for minority groups \\
\hline & & $\begin{array}{l}\text { ease of access for disadvantaged groups (e.g. poor, illiterate and elderly } \\
\text { people) }\end{array}$ \\
\hline
\end{tabular}




\subsubsection{Performance}

It is widely recognized that the first objective of ICT-enabled services and innovations is to improve efficiency and effectiveness of public management practices, and thus to ensure better and timely responsiveness, increasing the quality of public service delivery. In this sense interoperability plays a strategic role both for the increasing of efficiency and the effectiveness of the system. For what concerns efficiency, in fact, it is feasible to say that in the field of e-Government one possible measure of efficiency is the number of interactions required by users to provide useful information in order to complete a service. The final aim of interoperability is to make possible the seamlessly integration of the information systems of different public institutions in order to enable them to provide one-stop, automated services for citizens and business.

For what concerns effectiveness, on the other hand, interoperability is a fundamental tool for the automation of business processes for service provision. The final outcome of the service provision enabled by interoperable systems can be measured both in term of cost/benefit analysis and in terms of final users' perception of the accuracy and reliability of the service provision itself.

\subsubsection{Openness}

It is generally assumed that government systems functions best when they are open and accountable for their actions. Local communities are strong when all public administration's stakeholders understand and participate in the civic process and have access to good and clear information. Transparency in government is the basis for accountability, improved decision-making, public trust and informed participation. The principle of open, transparent government reaches virtually every aspect of a city government's operation - for example everything from the adoption of an ordinance to the posting of an annual budget or the way the city responds to a customer's inquiry about a water bill. Greater transparency can also have a transformational impact on how government serves those who live, work and invest in a city. Clear procedures and accessible, easy-to-understand records and information can promote the accountability of public servants as they make decisions and conduct the public's business and can invite the participation of residents to collaborate in the strengthening of governance processes. In this regard the role of interoperable systems is to provide access to information to all public administration's stakeholders. In this sense it is possible to identify two levels of access to information. The first one concerns the technological aspects, i.e. the diffusion of standards and technological infrastructures and systems enabling interoperability. The second one is more related to business processes and organizational dimensions and concerns the data sharing, i.e. the ability of administrations to access data by means of the inter-administration back-office, and the possibility for external users to access administrative data via ICTs.

\subsubsection{Inclusion}

Today inclusion is more widely thought of as a practice of ensuring that people in given societal or organisational setting feel they belong, are engaged, and connected to society or organization. Inclusion has indeed also a technological dimension, especially in the field of the provision of on-line public services and information, often called 'accessibility'. In Europe inclusion is considered an all-encompassing practice of ensuring that people with different abilities belong, are engaged, and are connected to society. That said, Europe is by no means homogeneous in relation to the degree with which inclusion as a topic or a definition is influenced by local conditions. Basically there are two main policy perspectives to consider when focusing on inclusion and ICTs: policies to help people use ICTs and the use of ICTs to help people [10].

On the other hand accessibility can also be thought as the effort made in order both to tackle various types of existing and emerging divides, and to respond to an increasing demand by citizens and businesses for high quality government services. In this sense interoperability systems must assure accessibility for different channels and supports - i.e. not only desktop PC but also mobile phones, TV, radio, etc. This could be a first important step to both provide high quality services and to expand the possibility for different citizens groups - disabled people, poor, illiterate and elderly people, or disadvantages groups in general - to use on-line information and public services.

\section{Conclusions and Future Research}

After discussing the multiple dimensions of interoperability within the $\mathrm{EU}$, the article presented a conceptual framework for ICT-enabled governance at the local level. It has analyzed the role of interoperability in this regard, suggesting that interoperability plays a strategic role in the delivery of e-Government services to local and national communities within the EU. It is expected that the significance of interoperability will increase over the next few years, especially in terms of how it supports emerging city governance models and acts as the backbone of communications at pan-European, national and local levels.

The thesis proposed in this article is that a conceptual model of interoperability focused on the local context should contemplate two distinct levels of analysis. The first level should consider the specific target category of the ICTenabled services. This analytical dimension can be called "service level" and it is largely focused on technical issues. The article also proposes a second complementary level of analysis underpinning the conceptual model that should be focused on the interplay between the policy, institutional and technical dimensions. 
This second level of analysis also looks at the benefits, but from a policy and organizational perspective - including public, private and third sector organisations in their roles as designers, providers or suppliers of the services. We refer to this dimension using the expression "governance level of analysis". This is because, for the institutions and organizations involved in the integration of the information systems, interoperability is not only a technical challenge but involves a significant change in policy, stakeholder relationships and organizational structures.

The framework presented in this article focuses on this second level of analysis. It aims to assess which elements of a governance model can influence the integration of information systems and business processes. Additionally, the framework attempts to set the basis for assessing how ICT-enabled collaboration across organizational boundaries can be appropriately implemented in different European governance contexts.

The article proposes that goal of the design and the implementation of interoperable systems should not merely be the enabling of multi-agency collaboration. As with many aspects of e-Government - and because interoperability is such an important element of it - a conceptual framework should also be focused on the overall public value created by interoperable systems in supporting ICT-enabled governance at the local level.

In this regard, the exploratory research project on emerging ICT-enabled governance models in EU cities (EXPGOV), conducted by the Information Society Unit of the Institute for Prospective Technological Studies (IPTS) of the European Commission's Joint Research Centre, is studying the interplay between ICTs and governance processes within cities throughout the EU. In doing so, the EXPGOV Project focuses on social, organizational and technological issues as key elements for the definition of the institutional and policy changes involved in the deployment of ICTenabled governance within European cities. The interim findings of this project suggest interoperability is a social, organizational and technological issue for the types of ICT-enabled governance models outlined in this article.

In view of this, we suggest that interoperability should be considered strategic not only from a technical perspective, but also from a theoretical and conceptual standpoint in e-Government and e-Governance research. Indeed we would go further and suggest that interoperability should be seen as a key element in the design of ICT-enabled governance models.

In conclusion, it is worth mentioning that, analysing the main issues that characterise interoperability in local government, solutions vary in scope and complexity. To this end, it is important to develop a context-specific framework to assess the various governance dimensions and identify the interoperability objectives, layers and implementation approaches and principles that are included in the overall framework itself.

A comprehensive framework should therefore provide a sound foundation for interoperability implementation plans and programmes, based on a vision which provides:

- A common framework for determining government-wide priorities for interoperability initiatives;

- $\quad$ Problems and needs assessment for the key targets;

- $\quad$ Agreed maturity levels of interoperability;

- Intended business features/innovations;

- Required actions to advance the vision/strategy;

- $\quad$ Strategic design and scenario alternatives; and

- A suggested plan and key milestones.

This framework should not be oriented to technical standards alone, but also to solving complex functional issues associated with the specific needs of the organisations involved.

In addition, this framework could be the initial basis for a monitoring and evaluation system of the implementation phase and, as a result, possible misalignment between policies, strategy and operations could be avoided.

Further research is required to better understand the role interoperable systems could play both in ICT-enabled governance models - especially at city level - and in the pan-European cross-border challenges posed by interoperability itself. 


\section{Acknowledgments}

This article is inspired by and in part drawn from the Exploratory Research on emerging ICT-enabled governance models in European cities (EXPGOV) conducted by Gianluca Misuraca as part of his work for the Information Society Unit of the Institute for Prospective Technological Studies (IPTS) of the European Commission's Joint Research Centre, in collaboration with EUROCITIES. Special thanks go to Prof. Mark Deakin and Peter Cruickshank from the Edinburgh Napier University, (Scotland, UK) for their review of a first draft of this article.

\section{References}

[1] J. Alford, Defining the client in the Public Sector: A social-exchange perspective, Public Administration Review, vol. 62, no. 3, pp. 337-346, 2002.

[2] F. Bannister, Citizen Centricity: A Model of IS Value in Public Administration, Electronic Journal of Information Systems Evaluation, vol. 5, no. 2, Article 1, 2002.

[3] R. L. Baskerville and A. T. Wood-Harper, Diversity in information systems action research methods, European Journal of Information Systems, 7, no. 2, pp. 90-107, 1998.

[4] C. Batini, G. Viscusi, and D. Cherubini, GovQual: a Quality Driven Methodology for eGovernment Project Planning. Government Information Quarterly, vol. 26, no. 1, pp. 106-117, 2009.

[5] W. Castelnovo, M. Simonetta. (2008, April). A Public Value Evaluation of e-Government Policies, The Electronic Journal Information Systems Evaluation. [Online]. vol. 11, no. 2, pp. 61-72. Available: http://www.ejise.com/issue/download.html?idArticle=577.

[6] M. Castells, The Rise of the Network Society. The Information Age: Economy, Society and Culture. Volume 1. Malden Mass., Oxford: Blackwell, 1997.

[7] P. Checkland, Systems Thinking, Systems Practice, Chichester: John Wiley \& Sons Ltd, 1999.

[8] A. Cherns, The principles of sociotechnical design, Human Relations, vol. 29, no. 8, pp. 783-792, 1976.

[9] C. Codagnone, P. Boccardelli, M. Corsi, A. Gumina, G. Galasso, P. Montironi, eGovernment Economics Project - First Workshop discussion document, in Proceedings of eGEP 1st Workshop, Rome, 2005.

[10] C. Codagnone (editor) Vienna Study on Inclusive Innovation for Growth and Cohesion: Modelling and demonstrating the impact of elnclusion. European Commission, 2009.

[11] W. M. Cohen and D. A. Levinthal, Absorptive Capacity: A New Perspective on Learning and Innovation, Administrative Science Quarterly, vol. 35, no. 1, pp. 128-152, 1990.

[12] F. Damanpour, Technology and productivity: A contingency analysis of computer in local governments, Administration and Society, vol. 11, no. 2, pp. 144-171, 1992.

[13] P. Dunleavy, H. Margetts, S. Bastow, and J. Tinkler, Digital Era Governance: IT Corporations, The State and eGovernment, New York: Oxford University Press, 2006.

[14] Esping-Andersen, The three World of Welfare Capitalism, Cambridge, Polity Press, 1990.

[15] European Commission, (2002), eEurope 2005: An information society for all. An Action Plan to be presented in view of the Sevilla European Council, 21/22 June 2002", $\operatorname{COM(2002)~} 263$ final of 28 May 2002. Available at: http://ec.europa.eu/information society/eeurope/2002/news library/documents/eeurope2005/ eeurope2005 en.pdf.

[16] European Commission, (2004), European Interoperability Framework for pan_European eGovernment Services, Working document of the IDA programme, Available: http://ec.europa.eu/idabc/servlets/Docd552.pdf?id=19529.

[17] European Commission, (2006), Interoperability for Pan-European e-Government Services, COM (2006) 45 final of 13th February 2006.

[18] European Commission, Joint Research Centre, Institute for Prospective Technological Studies (2010), Concept Paper of the Exploratory Research on emerging ICT-enabled governance models in EU cities. Available at: http://is.irc.ec.europa.eu/pages/EAP/documents/EXPGOVD4ConceptPaperDraftV1.0-22032010.pdf.

[19] EUROCITIES, (2009), City e-Government Benchlearning.

[20] J. E. Fountain, Public Sector: Early Stage of a deep transformation, in R.E., Litan (ed.), The Economic Payoff from the International Revolution, Washington D.C., Brookings Institution Press, 2001.

[21] J. Fountain, Notes on the impact of research on the development of eGovernment, European Review of Political Technologies, vol. 5, pp. 61-77, February 2008.

[22] R. C. Gilbert, The Challenging Role of Citizen in The e-Governance and e-Democracy Equation, Commonwealth Centre for e-Governance.

[23] P. Gottschalk, Maturity levels for interoperability in digital government, Government Information Quarterly, vol. 26, no. 1, pp. 75-81, 2009.

[24] S. Graham, S. Marvin, Telecommunications and the City: Electronic Spaces, Urban Places, New York: Routledge, 1996.

[25] C. Hay, Constructivist Institutionalism, in The Oxford Handbook of Political Institutions (R. Rhodes, S. Binder, B. Rockman, Eds.). UK: Oxford Univ. Press, pp. 56-74, 2006.

[26] A. R. Hevner, S. T. March, J. Park, and S. Ram, Design Science in Information Systems Research. MIS Quarterly, vol. 28, no. 1, pp. 75-105, 2004.

[27] C. Jacquier, Urban Governance: forging a path between complications and complexity, paper presented at the Towards New Territorial Governance, 2008.

[28] D. Jeffrey, J. Gliddens, L. Pratchett, and S. Ruston, (2006), Promoting Social Inclusion via e-Participation, The 2006 International e-Participation and Local Democracy Symposium. Available: 
http://portal.unesco.org/ci/en/ev.php-URL ID=22261\&URL DO=DO TOPIC\&URL SECTION=201.html

[29] I. Kearns, Public value and e-government, Institute for Public Policy Research (ippr), 2004.

[30] S. Krätke, Berlin: Towards a Global City?, in World Cities in a World-System (P. S. Knox and P. J. Taylor, Eds), Cambridge: Cambridge University Press, 1995.

[31] J. Loughlin, Subnational Democracy in the European Union. Challenges and Opportunities, Oxford University Press, 2004.

[32] S. T. March and G. F. Smith, Design and natural science research on information technology, Decision Support Systems, vol. 15, no. 4, pp. 251-266, 1995.

[33] J. Millard, J. S. Iversen, H. Kubicek, H. Westholm, R. Cimander, Reorganisation of Government Back Offices for Better Electronic Public Services - European Good Practices (Back-office reorganisation), Report to the European Commission, January $2004 . \quad$ Available at: http://www.oeaw.ac.at/ita/ebene5/back office reorganisation volume3.pdf.

[34] G. Misuraca, P. Rossel, M. Finger, Governance with and of ICTs: the need for new institutional design in a changing world, egov magazine, vol. 2, no. 5, May 2006.

[35] G. Misuraca, e-Governance in Africa from Theory to Action: a handbook on ICT for Local Governance, Africa World Press / IDRC, 2007.

[36] G. Misuraca and P. Rossel, Triggering the governance perspective of e-Government projects: beyond mere digitization of administration services, in Proceedings of the 3rd Global Knowledge Conference, Kuala Lumpur, Malaysia, 2007, pp. 11-13.

[37] G. Misuraca, e-Government 2015: Exploring m-government scenarios, between ICT-driven experiments and citizen-centric implications, Technology Analysis and Strategic Management, vol. 21, no. 3, pp. 18, 2009.

[38] G. Misuraca, G. Viscusi, e-Governance for Development: lessons learned and strategic principles for designing an operational roadmap, Special Issue on: Methodologies, Technologies and Tools Enabling e-Government, International Journal of Electronic Governance (IJEG), vol. 3, no. 2, pp. 118 - 133, 2010.

[39] G. Misuraca, Social Computing and Governance, in The impact of Social Computing on the EU Information Society and Economy (Y. Punie, W. Lusoli, C. Centeno, G. Misuraca, D. Broster, Eds.) IPTS, JRC, European Commission, 2009, pp 121-135.

[40] G. Misuraca and R. Zambrano, UNDP Primer on e-Governance for Public Administration Reform (UNDP New York, Working Documents - Unpublished), 2009.

[41] G. Misuraca, P. Rossel, and O. Glassey, Overcoming barriers to innovation in e-Government: the Swiss' way, In Understanding eGovernment in Europe: issues and challenges edited by (P. G. Nixon, V. N. Koutrakou, and Rajash Rawal, Eds.) Routledge, Taylor and Francis Publisher, 2009, pp. 212-218.

[42] G. Misuraca, E. Ferro, and B. Caroleo, Assessing emerging ICT-enabled governance models in European cities: results from a mapping survey, in Proceedings of the eGOV2010 Conference, Lausanne, 2010, pp. 168-179.

[43] R. E. Mytinger, Innovation in local health services: A study of the adoption of new programs by local health departments with particular reference to new health practices. Washington, DC: U.S. Department of Health Education and Welfare, Public Health Services, Division of Medical Care Administration, 1968.

[44] OECD, The e-Government Imperative, e-Government Studies, 2003.

[45] J. R. Rodríguez, J. Batlle, and D. Esteban, e-Government City Models: cases from European cities, EUROCITIES.

[46] V. Schmidt, Discursive institutionalism: The explanatory power of ideas and discourse, Annual Review of Political Science, vol. 11, pp. 303-326, June 2008.

[47] A. C. Smith, D. A. Taebel, Administrative innovation in municipal government, International Journal of Public Administration, vol. 7, no. 2, pp. 149-177, 1985.

[48] E. L. Trist and H. Murray, Volume II: The Socio-Technical Perspective, The Social Engagement of Social Science, A Tavistock Anthology, University of Pennsylvania Press, 1993.

[49] UNDESA, 2003, World Public Sector Report 2003: e-Government at the Crossroads. Available at: http://unpan1.un.org/intradoc/groups/public/documents/un/unpan012733.pdf.

[50] UNDP, 2007, e-Government Interoperability Study Group: Overview and Guide. Available at: http://www.apdip.net/projects/gif/GIF-Overview.pdf.

[51] G. Viscusi, C. Batini, M. Mecella, Information Systems for eGovernment: a quality of service perspective, Heidelberg: Springer, 2010.

[52] D. M. West, (2000), Assessing e-government: The Internet, democracy, and service delivery by state and federal governments. Providence, RI: Taubman Center for Public Policy, Brown University. Available at: http://www.brown.edu/Departments/Taubman Center/polreports/egovtreport00.html. 